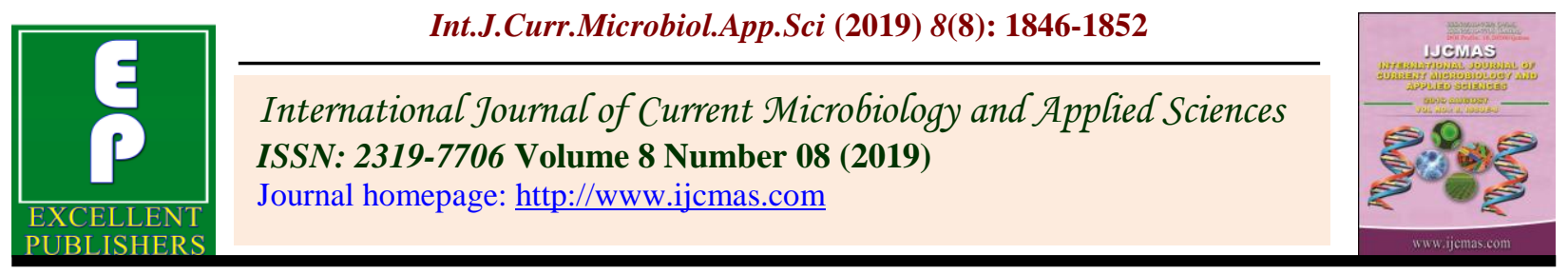

Original Research Article

https://doi.org/10.20546/ijcmas.2019.808.217

\title{
Effect of Foliar Spray of Plant Growth Regulators on Growth and Quality of Sprouting Broccoli (Brassica oleracea var. italica L.)
}

\author{
Pooja Chanwala, A.K. Soni*, Deepika Sharma and Gulab Choudhary
}

Department of Horticulture, S.K.N College of Agriculture, Jobner-303329, Rajasthan

*Corresponding author

\section{A B S T R A C T}

The experiment consisted of sixteen treatment combination including four NAA (control, NAA@80, NAA @ 120 and NAA @ 180 ppm) and four $\mathrm{GA}_{3}$ levels (control, GA $\mathrm{GA}_{3} @ 25$, $\mathrm{GA}_{3} @ 50$ and $\mathrm{GA}_{3} @ 75 \mathrm{ppm}$ ) were undertaken randomized block design (RBD) with

\begin{tabular}{|l|}
\hline Ke y w or d s \\
NAA, GA, Broccoli \\
and plant growth \\
regulators
\end{tabular}
three replications at Horticulture Farm S.K.N College of Agriculture, Jobner (Jaipur) during rabi 2018-19. The result of study clearly indicated that application of NAA @ 180 ppm to the sprouting broccoli significantly increased the plant height $(58.32 \mathrm{~cm})$, number of leaves $(25.85)$, leaf area $\left(1255.35 \mathrm{~cm}^{2}\right)$, chlorophyll content in leaves $(2.99 \mathrm{mg} / 100 \mathrm{~g})$, total yield per plot $(6.42 \mathrm{~kg})$, total yield per hectare (198.25 q), ascorbic acid content $(81.20 \mathrm{mg} / 100 \mathrm{~g})$, protein content $(2.38 \%)$ and curd fiber content $(0.380 \%)$ as compared to control and found statically at par to NAA @ 120 ppm. Similarly, GA 3 @ 75 ppm significantly increased the plant height $(57.95 \mathrm{~cm})$, number of leaves $(25.76)$, leaf area $\left(1145.05 \mathrm{~cm}^{2}\right)$, chlorophyll content in leaves $(2.95 \mathrm{mg} / 100 \mathrm{~g})$, total yield per plot $(6.44$ $\mathrm{kg})$, total yield per hectare $(198.64 \mathrm{q})$, ascorbic acid content $(80.12 \mathrm{mg} / 100 \mathrm{~g})$, protein content $(2.25 \%)$ and curd fiber content $(0.360 \%)$ as compared to control and statistically at par to $\mathrm{GA}_{3} @ 50$ ppm. The interaction effect of NAA@180 ppm and $\mathrm{GA}_{3} @ 75$ ppm $\left(\mathrm{N}_{3} \mathrm{G}_{3}\right)$ was recorded maximum leaf area $\left(1528.62 \mathrm{~cm}^{2}\right)$, yield per plot $(8.21 \mathrm{~kg})$ and yield per hectare $(253.25 \mathrm{q} / \mathrm{ha})$ which was significantly higher over rest of treatment combinations but statistically at par to $\mathrm{N}_{3} \mathrm{G}_{2}, \mathrm{~N}_{2} \mathrm{G}_{2}$ and $\mathrm{N}_{2} \mathrm{G}_{3}$.

\section{Introduction}

Broccoli (Brassica oleracea var. italica L.), belongs to family Brassicaceae and member of Cole group. The term 'Cole' originated from the word 'Colewort' meaning 'wild cabbage'. It is also known as 'green gobhi'. Among the growth regulators, auxin causes enlargement of plant cell and Gibberellins stimulates cell division, cell enlargement or both (Nickell, 1982). Gibberellic acid $\left(\mathrm{GA}_{3}\right)$ and Naphthalene acetic acid (NAA) exhibited beneficial effect in several crops (Sharma and Sardana, 2012; Thapa et al., 2013; Gayakvad et al., 2014). Due to diversified use of productive land, it is necessary to increase the food production and growth regulators may a contributor in achieving the desired goal.

NAA is synthetic plant hormone in the auxin group and is an ingredient in many commercial plants rooting horticultural product, it is rooting agent is use for vegetative propagation of plants, from stem 
and leaf cutting, plant tissue culture. NAA has been shown to greatly increase cellulose fibre formation in plants when paired with another phyto-hormone called gibberellic acid. Because it is in the auxin group it has also been understood to prevent pre-mature dropping and thinning of fruits from stems. It is applied after blossom fertilization. NAA present in environment undergoes oxidation reactions with hydroxyl radicals and sulphate radicals.

A radical reaction of NAA was studied by using pulses radiolysis technique. The growth substance like Naphthalene Acetic Acid (NAA) affects plants very much it may be useful in regulation of growth development and flowering of plant and also involved in biosynthetic process of plant and works with enzymes.

$\mathrm{GA}_{3}$ accumulation of dry matter, minerals and carbohydrates stimulates the cell of germinating seeds to produced mRNA molecules that code for hydrolytic enzymes. Gibberellic acid increases fresh and dries weight leaves and curd of cauliflower in association with NAA and Molybdenum (Muthoo et al., 1987).

\section{Materials and Methods}

The experiment was laid out at Horticulture farm, S.K.N. College of Agriculture, Jobner, District Jaipur during Rabi season, 2018-19. Geographically, Jobner is situated $45 \mathrm{~km}$ in West of Jaipur on $26^{0} 5^{\prime}$ North latitude, $75^{\circ} 20^{\prime}$ East longitude and at an attitude of 427 meters above mean sea level. The experiment consisted of sixteen treatment combination including four NAA (control, NAA @ 80, NAA @ 120 and NAA @ 180 ppm) and four $\mathrm{GA}_{3}$ levels (control, GA 3 @ 25, GA 3 @50 and $\mathrm{GA}_{3} @ 75$ ppm) were undertaken randomized block design (RBD) with three replications. The observations on various traits like weight of primary head, weight of secondary head, diameter of head, total yield per plots, total yield per hectare were recorded as per standard method.

\section{Results and Discussion}

\section{Growth attributes}

\section{Effect of NAA}

It is revealed from the Table 1,2 and 4 that The maximum plant height $(22.05,49.50$ and $58.32 \mathrm{~cm})$, number of leaves $(7.55,17.50$ and $25.85 \mathrm{~cm}$ ) at 30,60 and 90 DAT, chlorophyll content $(2.99 \mathrm{mg} / 100 \mathrm{~g})$, leaf area (1255.35 $\left.\mathrm{cm}^{2}\right)$, yield per plot $(6.42 \mathrm{~kg})$ and yield per hectare (198.25 q) were recorded with NAA @ 180 ppm $\left(\mathrm{N}_{3}\right)$ were recorded under $\left(\mathrm{N}_{3}\right)$ treatment $(180 \mathrm{ppm})$ and this treatment at par with $\mathrm{N}_{2}$ i.e. $120 \mathrm{ppm}$.

The superiority in growth parameters of different treatments over control was due to enhancement in morphological parameters by the mixture of NAA (through seed dressing) may be due to their effect on cell enlargement, cell growth, physio-chemical properties of protoplasm, respiration, nitrogen and nucleic acid metabolism etc. NAA promoted cell division in peri cycle and cortical tissue, the pattern was similar as occurring during lateral root development. The beneficial influence of plant growth regulators on growth parameters of horticultural crops have also been reported by Gupta et al., (2001), Khamparia and Tiwari (2006).

\section{Effect of $\mathrm{GA}_{3}$}

It is revealed from the Table 1,2 and 4 that The maximum plant height $(21.05,47.40$ and $57.95 \mathrm{~cm})$, number of leaves $(7.48,17.69$ and $25.76 \mathrm{~cm}$ ) at 30, 60 and 90 DAT, chlorophyll content $(2.95 \mathrm{mg} / 100 \mathrm{~g})$, leaf area $(1145.05$ $\left.\mathrm{cm}^{2}\right)$, yield per plot $(6.44 \mathrm{~kg})$ and yield per 
hectare (198.64 q) were recorded with $\mathrm{GA}_{3} @$ $75 \mathrm{ppm} \mathrm{G}_{3}$ and this treatment was also at par with $\mathrm{G}_{2}$ treatment i.e. $50 \mathrm{ppm}$ of $\mathrm{GA}_{3}$. Superiority in growth parameters due to foliar application of different concentrated $\mathrm{GA}_{3}$ over control possibly for due to the physiological effects of gibberellins on growth parameters of plants like cell elongation and cell division, increase in photosynthetic activity and better food accumulation.

Early head initiation and maturity may be due to the suppressive action of $\mathrm{GA}_{3}$ on apical meristem and with gibberellic acid. Foliar application of $\mathrm{GA}_{3}$ was also increased the growth characteristics in cabbage Yadav et al., (2000) and Manjit et al., (2011), Patil et al., (2003) in knol-khol.

\section{Quality attributes}

\section{Effect of NAA}

The data presented in Table 7 indicate the significant effect of NAA on quality attributes of head. Maximum ascorbic acid content $(81.20 \mathrm{mg} / 100 \mathrm{~g})$, crude protein content $(2.38$ $\%)$ and nitrogen content $(0.380 \%)$ as found in head of sprouting broccoli. The maximum values for all this quality attributes were found significantly superior in NAA @ 180 ppm treatment. These quality attributes were found at par in NAA @ 120 ppm and attributes were minimum in control. Similar tread was also observed by Patil et al., (1987); Sawant et al., (2010) Chaurasiya et al., (2014); and Muthoo et al., (1987).

Table.1 Effect of foliar spray of plant growth regulators on plant height and number of leaves of sprouting broccoli

\begin{tabular}{|c|c|c|c|c|c|c|}
\hline \multirow{2}{*}{$\begin{array}{l}\text { Treatment } \\
\text { NAA Levels }\end{array}$} & \multicolumn{3}{|c|}{ Plant height (cm) } & \multicolumn{3}{|c|}{ Number of leaves } \\
\hline & 30 DAT & 60 DAT & 90 DAT & 30 DAT & $60 \mathrm{DAT}$ & 90 DAT \\
\hline $\mathbf{N}_{0}$-Control & 13.20 & 28.15 & 41.50 & 5.05 & 10.20 & 15.20 \\
\hline $\mathrm{N}_{1}-80 p p m$ & 15.10 & 35.10 & 49.20 & 5.10 & 16.95 & 21.30 \\
\hline $\mathrm{N}_{2}-120 p p m$ & 18.40 & 39.05 & 55.50 & 6.25 & 17.05 & 24.10 \\
\hline $\mathrm{N}_{3}-180 p p m$ & 22.05 & 49.50 & 58.32 & 7.55 & 17.50 & 25.85 \\
\hline SEm \pm & 0.51 & 1.09 & 1.47 & 0.17 & 0.43 & 0.63 \\
\hline $\mathrm{CD}(\mathrm{p}=\mathbf{0 . 0 5})$ & 1.46 & 3.14 & 4.26 & 0.50 & 1.26 & 1.81 \\
\hline \multicolumn{7}{|l|}{$\mathbf{G A}_{3}$ Levels } \\
\hline $\mathbf{G}_{0}$-Control & 12.50 & 30.05 & 40.05 & 5.12 & 12.53 & 14.20 \\
\hline $\mathbf{G}_{1-25}$ ppm & 16.05 & 36.10 & 50.10 & 5.17 & 14.25 & 22.42 \\
\hline$G_{2-50} p p m$ & 19.15 & 38.25 & 56.42 & 6.18 & 17.23 & 24.07 \\
\hline $\mathbf{G}_{3}-75$ ppm & 21.05 & 47.40 & 57.95 & 7.48 & 17.69 & 25.76 \\
\hline SEm \pm & 0.51 & 1.09 & 1.47 & 0.17 & 0.43 & 0.63 \\
\hline $\mathrm{CD}(\mathrm{p}=0.05)$ & 1.46 & 3.14 & 4.26 & 0.50 & 1.26 & 1.81 \\
\hline
\end{tabular}


Table.2 Effect of foliar spray of plant growth regulators on chlorophyll content $(\mathrm{mg} / 100 \mathrm{~g})$ and leaf area $\left(\mathrm{cm}^{2}\right)$ of sprouting broccoli

\begin{tabular}{|c|c|c|}
\hline Treatment & Chlorophyll content $(\mathrm{mg} / \mathbf{1 0 0 g})$ & Leaf area $\left(\mathrm{cm}^{2}\right)$ \\
\hline \multicolumn{3}{|l|}{ NAA Levels } \\
\hline $\mathbf{N}_{0}$-Control & 2.01 & 750.20 \\
\hline $\mathrm{N}_{1}-80 \mathrm{ppm}$ & 2.35 & 825.35 \\
\hline $\mathrm{N}_{2}-120 \mathrm{ppm}$ & 2.65 & 930.50 \\
\hline $\mathrm{N}_{3}-180 \mathrm{ppm}$ & 2.99 & 1255.35 \\
\hline SEm \pm & $\mathbf{0 . 0 7}$ & 9.19 \\
\hline $\mathrm{CD}(\mathrm{p}=0.05)$ & 0.21 & 26.55 \\
\hline \multicolumn{3}{|l|}{ GA $_{3}$ Levels } \\
\hline $\mathbf{G}_{0}$-Control & 2.15 & 820.45 \\
\hline $\mathrm{G}_{1}-25 \mathrm{ppm}$ & 2.20 & 850.50 \\
\hline$G_{2}-50$ ppm & 2.70 & 945.40 \\
\hline$G_{3}-75$ ppm & 2.95 & 1145.05 \\
\hline SEm \pm & 0.07 & 9.19 \\
\hline $\mathrm{CD}(\mathrm{p}=0.05)$ & 0.21 & 26.55 \\
\hline
\end{tabular}

Table.3 Interactive effect of NAA and $\mathrm{GA}_{3}$ levels on leaf area $\left(\mathrm{cm}^{2}\right)$

\begin{tabular}{|l|l|l|l|l|l|}
\hline & $\mathbf{N}_{\mathbf{0}}$ & $\mathbf{N}_{\mathbf{1}}$ & $\mathbf{N}_{\mathbf{2}}$ & $\mathbf{N}_{\mathbf{3}}$ & Mean \\
\hline $\mathbf{G}_{\mathbf{0}}$ & 654.55 & 720.11 & 811.86 & 1095.29 & 3281.81 \\
\hline $\mathbf{G}_{\mathbf{1}}$ & 678.52 & 746.49 & 841.59 & 1135.40 & 3402 \\
\hline $\mathbf{G}_{\mathbf{2}}$ & 754.23 & 829.78 & 935.50 & 1262.09 & 3781.6 \\
\hline $\mathbf{G}_{\mathbf{3}}$ & 913.51 & 1005.02 & 1133.06 & 1528.62 & 4580.21 \\
\hline Mean & 3000.81 & 3301.4 & 3722.01 & 5021.4 & 15045.62 \\
\hline
\end{tabular}

Table.4 Effect of foliar spray of plant growth regulators on total per plot and per hectare of sprouting broccoli

\begin{tabular}{|c|c|c|}
\hline Treatment & Total yield per plot (kg) & Total yield per ha (q.) \\
\hline \multicolumn{3}{|l|}{ NAA Levels } \\
\hline $\mathbf{N}_{0^{-}}$-Control & 2.54 & 78.37 \\
\hline $\mathrm{N}_{1}-80 \mathrm{ppm}$ & 5.06 & 156.06 \\
\hline $\mathrm{N}_{2}-120 \mathrm{ppm}$ & 6.17 & 190.41 \\
\hline $\mathrm{N}_{3}-180 \mathrm{ppm}$ & 6.42 & 198.25 \\
\hline SEm \pm & 0.13 & 3.63 \\
\hline $\mathrm{CD}(\mathrm{p}=0.05)$ & 0.38 & 10.49 \\
\hline \multicolumn{3}{|l|}{ GA $_{3}$ Levels } \\
\hline $\mathbf{G}_{0}$-Control & 2.68 & 82.84 \\
\hline $\mathrm{G}_{1}-25 \mathrm{ppm}$ & 4.92 & 151.91 \\
\hline$G_{2}-50$ ppm & 6.15 & 189.69 \\
\hline$G_{3}-75$ ppm & 6.44 & 198.64 \\
\hline SEm \pm & 0.13 & 3.63 \\
\hline $\mathrm{CD}(\mathrm{p}=0.05)$ & 0.38 & 10.49 \\
\hline
\end{tabular}


Table.5 Interactive effect of NAA and $\mathrm{GA}_{3}$ levels on total yield per plot $(\mathrm{Kg})$ of sprouting broccoli

\begin{tabular}{|c|c|c|c|c|c|}
\hline & $\mathbf{N}_{0}$ & $N_{1}$ & $\mathbf{N}_{2}$ & $\mathbf{N}_{3}$ & Mean \\
\hline $\mathbf{G}_{\mathbf{0}}$ & 1.41 & 2.69 & 3.25 & 3.38 & 10.73 \\
\hline $\mathbf{G}_{1}$ & 2.47 & 4.93 & 6.02 & 6.27 & 19.69 \\
\hline $\mathbf{G}_{\mathbf{2}}$ & 3.06 & 6.16 & 7.53 & 7.84 & 24.59 \\
\hline $\mathbf{G}_{\mathbf{3}}$ & 3.21 & 6.45 & 7.88 & 8.21 & 25.75 \\
\hline Mean & 10.15 & 20.23 & 24.68 & 25.7 & 80.76 \\
\hline
\end{tabular}

Table.6 Interactive effect of NAA and $\mathrm{GA}_{3}$ levels on total yield per hectare (q) of sprouting broccoli

\begin{tabular}{|l|l|l|l|l|l|}
\hline & $\mathbf{N}_{\mathbf{0}}$ & $\mathbf{N}_{\mathbf{1}}$ & $\mathbf{N}_{\mathbf{2}}$ & $\mathbf{N}_{\mathbf{3}}$ & Mean \\
\hline $\mathbf{G}_{\mathbf{0}}$ & 43.62 & 83.03 & 100.31 & 104.39 & 331.35 \\
\hline $\mathbf{G}_{\mathbf{1}}$ & 76.15 & 152.19 & 185.83 & 193.49 & 607.66 \\
\hline $\mathbf{G}_{\mathbf{2}}$ & 94.59 & 190.02 & 232.29 & 241.87 & 758.77 \\
\hline $\mathbf{G}_{\mathbf{3}}$ & 99.12 & 198.99 & 243.21 & 253.25 & 794.57 \\
\hline Mean & 313.48 & 624.23 & 518.43 & 793 & 2492.35 \\
\hline & & & & & \\
\hline
\end{tabular}

Table.7 Effect of foliar spray of plant growth regulators on Ascorbic acid nitrogen and crude protein content in head of sprouting broccoli

\begin{tabular}{|c|c|c|c|}
\hline Treatment & $\begin{array}{l}\text { Ascorbic acid content in } \\
\text { head }(\mathrm{mg} / \mathbf{1 0 0 g})\end{array}$ & $\begin{array}{l}\text { Nitrogen content } \\
\text { in head }(\%)\end{array}$ & $\begin{array}{l}\text { Crude protein } \\
\text { content in head } \\
(\%)\end{array}$ \\
\hline \multicolumn{4}{|l|}{ NAA Levels } \\
\hline $\mathrm{N}_{0}$-Control & 65.33 & 0.250 & 1.56 \\
\hline $\mathrm{N}_{\mathbf{1}}-80 \mathrm{ppm}$ & 73.85 & 0.330 & 2.06 \\
\hline $\mathrm{N}_{2}-120 \mathrm{ppm}$ & 78.76 & 0.350 & 2.19 \\
\hline $\mathrm{N}_{3}-180 \mathrm{ppm}$ & 81.20 & 0.380 & 2.38 \\
\hline SEm \pm & 2.11 & 0.009 & 0.06 \\
\hline $\mathrm{CD}(\mathrm{p}=0.05)$ & 6.10 & 0.027 & 0.17 \\
\hline \multicolumn{4}{|l|}{ GA $_{3}$ Levels } \\
\hline $\mathbf{G}_{0}$-Control & 69.80 & 0.290 & 1.81 \\
\hline $\mathrm{G}_{1}-25 \mathrm{ppm}$ & 72.16 & 0.320 & 2.00 \\
\hline$G_{2}-50$ ppm & 77.06 & 0.340 & 2.13 \\
\hline $\mathrm{G}_{3}-75 \mathrm{ppm}$ & 80.12 & 0.360 & 2.25 \\
\hline SEm \pm & 2.11 & 0.009 & 0.06 \\
\hline $\mathrm{CD}(\mathrm{p}=0.05)$ & 6.10 & 0.027 & 0.17 \\
\hline
\end{tabular}




\section{Effect of $\mathbf{G A}_{3}$}

The data presented in Table 7 indicate that the plant growth regulator treatments significantly increased the ascorbic acid $(80.12 \mathrm{mg} / 100 \mathrm{~g})$, nitrogen content $(0.360 \%)$ and curd protein content $(2.25 \%)$ in sprouting broccoli. Significant increase in ascorbic acid content of the head were found by spraying $\mathrm{GA}_{3} 75 \mathrm{ppm}$, then other treatments but the treatment $\mathrm{GA}_{3} 50 \mathrm{ppm}$ at par to it. Chauhan and Tandel (2009) reported that application of $\mathrm{GA}_{3}$ increased the ascorbic acid content in cabbage. The increased vegetative growth influence other characters might have promoted the metabolic activities of the plants due to application of plant growth regulators such as $\mathrm{GA}_{3}$ increased the vitamin $\mathrm{C}$ content of the broccoli heads, which is ultimately improvement in quality of sprouting broccoli heads.

\section{Interactive effect of NAA and $\mathrm{GA}_{3}$}

The result in table 3,5 and 7 indicated significant variation in treatments from control due to effect of GA3 and NAA on growth and yield attributes. The maximum leaf area $\left(1528.62 \mathrm{~cm}^{2}\right)$, yield per plot $(8.21$ $\mathrm{kg})$ and yield per hectare $(253.25 \mathrm{q} / \mathrm{ha})$ were recorded with treatment NAA @ 180 ppm and $\mathrm{GA}_{3} @ 75 \mathrm{ppm}\left(\mathrm{N}_{3} \mathrm{G}_{3}\right)$ lowest in control $\mathrm{N}_{0} \mathrm{G}_{0}\left(654.55 \mathrm{~cm}^{2}, 1.41 \mathrm{~kg}\right.$ and $\left.43.62 \mathrm{q} / \mathrm{ha}\right)$. This might be due to more accumulation of and carbohydrate by maximum rate of photosynthesis and increasing the cell elongation, cell division and cell expansion that might be effect the increase in yield and also due to the higher accumulation of food (Thapa et al., 2013 in broccoli).

\section{References}

Chauhan, U.M. and Tandel, Y.N. 2009. Effect of plant growth regulators on growth, yield and quality of cabbage (Brassica oleracea var. capitata L.) cv. Golden Acre. The Asian Journal of Horticulture, 4 (2): 512-514. Chaurasiya, J., Meena, M.L., Singh, H.D., Adarshand, A. and Mishra, P.K. 2014. Effect of $\mathrm{GA}_{3}$ and NAA on growth and yield of cabbage (Brassica oleracea var. capitata L.) cv. Pride of India. The Bioscan, 9 (3): 1139-1141.

Gayakvad, P., Jadeja, D. B., Tandel, M.B., Parmar, M. R., Bhalawe, S. and Nayak, D. 2014. Effect of foliar application of $\mathrm{GA}_{3}$, ethrel and copper sulphate on flowering behaviour and yield of Jatropha Curcas L. The Bioscan. 9 (2): 485-490.

Gupta, P.K., Gupta, A.K. and Reddy, S. 2001. Efficiency of plant growth regulators and micronutrients mixtures on growth yield and shelf life of tomato fruits (Lycopersicon esculentum Mill.). Indian Journal of Agricultural Biochemistry, 14 (1\&2): 63

Khamparia, S.K. and Tiwari, K. 2006. Effect of growth regulators on yield, nutritional and storage qualities of onion bulb. Annals of Plant Soil Research, 9 (1): 33-35.

Manjit, Rana, Rawat D.K., J.M.S. and Rawat, S.S. 2011. Effect of $\mathrm{GA}_{3}$ and Kinetin on growth, yield and quality of sprouting broccoli (Brassica oleracea var italica L). Journal of Horticulture and Forestry, 3 (9): 282-285.

Muthoo, A.K., Kumar, S. and Maurya, A.N. 1987. Studies on the effect of foliar application of $\mathrm{GA}_{3}$, NAA and molybdenum on growth and yield of cauliflower cv. Snowball-16.Haryana Journal of Horticulture Science, 16 (12): 115-220.

Nickell, L.G. 1982. Plant Growth Regulators, Springer- Verlag Berlin Heidelberg, New York. Pp. 1-3.

Patil, S. S., Patil, B. S. and Ingle, V. G. 2003. Effect of foliar application of growth 
regulators on growth and yield of knolkhol cv. White Vienna. Annals of Plant physiology, 17 (1): 56-59.

Patil, V.S. and Patil, A.A. 1987. Effect of NAA and $\mathrm{GA}_{3}$ on growth and yield of cabbage (Brassica oleracea var. capitata L.) varieties. Progressive Horticulture, 19 (2): 50-52.

Sawant, V.P., Naik, D.M., Barkule, A.M. and Shinde, S.B. 2010. Effect of foliar application plant growth regulators on growth, yield and quality of cabbage cv. Golden Acre. Asian Journal of Horticulture, 5 (2): 495-497.

Sharma, P. and Sardana, V. 2012. Effect of growth regulating substances on the chlorophyll, nitrate reductase, leghaemoglobin content and yield in groundnut (Arachis hypogaea). The Bioscan. 7 (1): 13-17.

Thapa, U., Das, R., Mandal, A.R. and Debanath, S. 2013. Influence of $\mathrm{GA}_{3}$ and NAA on growth, yield and quality attributing characters of sprouting broccoli (Brassica oleracea . var. Italica L.) Crop Research, 46 (1, 2 \& 3): 192195.

Yadav, R.L., Dhaka, R.S. and Fageria, M.S. 2000. Effect of $\mathrm{GA}_{3}$, NAA and succinic acid on growth and yield of cabbage cv. Golden Acre. Haryana Journal of Horticulture Science, 29 (3 \& 4): 269270.

\section{How to cite this article:}

Pooja Chanwala, A.K. Soni, Deepika Sharma and Gulab Choudhary. 2019. Effect of Foliar Spray of Plant Growth Regulators on Growth and Quality of Sprouting Broccoli (Brassica oleracea var. italica L.). Int.J.Curr.Microbiol.App.Sci. 8(08): 1846-1852.

doi: https://doi.org/10.20546/ijcmas.2019.808.217 